\title{
Recognition of Prior Learning in Degree Programs in Practice
}

\author{
${ }^{1}$ Rolf Erhardt, M. Eng., ${ }^{2}$ Prof. Dr.-Ing. Ulrich Schmitt \\ ${ }^{1}$ Scientific assistant, Aalen University, Beethovenstraße 173430 Aalen, Germany \\ ${ }^{2}$ Professor in Mechatronics, Aalen University, Beethovenstraße 173430 Aalen, Germany \\ Email: Rolf.Erhardt@hs-aalen.de, Ulrich.Schmitt@hs-aalen.de
}

\begin{abstract}
In the year 2002 Germany ratified the Lisbon Convention which contained the recognition of prior learning. After some changes in the state law on universities and colleges regarding the access to higher education it is now possible for people with advanced vocational training to access higher education. Furthermore, professional skills may be credited toward the study course. Usually, this recognition does not lead to a shortened duration of study. Aalen University developed a model in the area of engineering sciences with a reduced duration of study lasting 7 to 5 semesters. The first group recently graduated.
\end{abstract}

Keywords: Recognition of prior learning, Lisbon convention, reduced duration of study, nontraditional students, mechatronics

\section{Introduction}

Because of the upcoming shortage in skilled professionals mostly in the engineering sector $\left(\mathrm{EFI}^{1}, 2011\right)$ not least due to demographic change $\left(\mathrm{DIHK}^{2}, 2012\right)$ the following question arises: How can new target groups be introduced to academic studies and be enabled to perform well?

"The transition of professional qualified people to university is an important point in education policy and recognition of prior learning is an important tool." (Freitag, W. K. et. al., 2011, p. 9)

Regarding access to higher education for non-traditional students, Germany ranks in $13^{\text {th }}$ place among the 23 members in the EU. Germany thus holds an enormous potential for improvement (Orr, Gwosc, \& Netz, 2011). The recognition of prior learning is one of the steps for reaching a higher permeability in the education system.

Experts agree that skills which have been already achieved should not be taught again. The legal foundation for the recognition of prior learning in Germany are multiple resolutions from the Standing Conference of the Ministers of Education and Cultural Affairs of the Länder (sic) (KMK ${ }^{3}, 2002$ and KMK, 2008).

These in turn are based on the Convention on the Recognition of Qualifications concerning Higher Education of the European Region Lisbon, 1997 (Bonn, 2007). For most federal states in Germany a corresponding regulation is embedded in the state law on universities and colleges. In case of BadenWurttemberg the regulations can be found in $\mathrm{LHG}^{4} \S 35$ Recognition of skills (Land BadenWürttemberg, 2005). Universities need to provide appropriate regulations in their study guidelines. Since 01/01/2015 these regulations have been examined during (re)accreditation of degree programs. If regulations for the recognition of skills are missing or insufficient, obligations are imposed on the program (Akkreditierungsrat, 2014).

\footnotetext{
${ }^{1}$ EFI stands for "Expertenkommission Forschung und Innovation", in English "expert commission research and innovation"

${ }^{2}$ DIHK stands for "Deutscher Industrie- und Handelskammertag", in English "The Association of German Chambers of Commerce and Industry"

${ }^{3}$ KMK stands for "Kultusministerkonferenz", in English "Standing Conference of the Ministers of Education and Cultural Affairs of the Länder"

${ }^{4}$ LHG stands for "Landeshochschulgesetz, in English "State law on universities and colleges"
} 


\section{Methodology}

Typically an accordance of $75 \%$ or more is requested for a positive decision (Martens, Diettrich, \& Kati, 2014, p. 18). If a recognition is declined, this always has to be justified. If the grading systems are not compatible, the skill is recognized without grade, details have to be regulated in the study guidelines. If multiple modules can be recognized, it might be possible to shorten the duration of study. Companies view this reduction of the duration of study as a great chance: Academic studies become more efficient, because "studying employees are less missing from business operating process" (Freitag, W. K. et. al., 2011, p. 156). The major part of businesses regard recognition of prior learning as a contribution for covering the demand of skilled personnel (op. cit.).

In general, recognition of prior learning is differentiated in two types: individual and overall recognition. Individual recognition means the examination of an individual student and his skills. This refers to examining formal, non-formal and informal skills (ANKOM ${ }^{5}, 2010$, p. 16).

Overall recognition means the comparative check between a professional (formal) and an academic skill, disregarding actual students (ANKOM, 2010, p. 17).

If this comparison has been done once, it is valid for all students holding the checked professional skill. No further examination needs to be done (Freitag, W. K. et. al., 2011, p. 6). This reduces the workload during operation significantly.

Methods of equivalence checks can be distinguished as follows:

- Weakly structured

- $\quad$ Moderately structured

- $\quad$ Strongly structured

In weakly structured examinations, a professor takes a decision based upon presented documents. In moderately structured examinations the professor is supported by checklists or guidelines e.g. In case of strongly structured examination he is methodically supported by systematic tools, which can be interpreted as monitoring procedure (ANKOM, 2010, p. 13). For this purpose, Dr. Wolfgang Müskens from the Carl Ossietzky University Oldenburg developed module level indicator (MLI). With this tool, the accordance between academic and non-academic competences can be assessed by means of 51 elements. According to studies the MLI holds a high reliability (ANKOM, 2010, S. 15), but requires high effort.

Reduction of the duration of study is an important element to increase the involvement of nontraditional students (Nickel \& Leusing, 2009, p. 29). In case of individual recognition this shortening is very difficult or even impossible to realize. In most cases the identified modules are located in different semesters, so the curriculum cannot consider the needs of individual students. However, for a homogeneous cohort and by the use of overall recognition a significant reduction of the duration of study becomes possible.

In Germany the Standing Conference of the Ministers of Education and Cultural Affairs of the Länder specified a limit of 50 percent recognition of professional skills on academic studies (KMK, 2002).

There are already successful examples for the reduction of the duration of studies, mostly in the area of social sciences. During the first ANKOM initiative, the course of studies "Erziehung und Bildung im Kindesalter ${ }^{6}$ " at the Alice Salomon University Berlin developed the possibility of overall recognition for applicants holding professional skills. To ensure this overall recognition, collaborations were established with three professional schools. Applicants from these schools get 90 ECTS recognized on their course of studies. 90 ECTS are equivalent to three semesters, the complete duration of the regular course is seven semesters (Kruse, 2012, p. 11).

Meanwhile several other courses of studies in the field of social sciences are taking a similar direction, such as the Catholic University of Applied Sciences Freiburg. Applicants from cooperating professional schools get 60 ECTS recognized in their bachelor course "Pädagogik", so the former seven semester course is reduced to five semesters (Freiburg, 2015).

\footnotetext{
${ }^{5}$ ANKOM stands for "Anrechnung beruflicher Kompetenzen auf Hochschulstudiengänge", in English "Recognition of prior learning in degree programs"

${ }^{6}$ Education and upbringing in early childhood
} 


\section{$3 \quad$ Recognition in the Area of Engineering Sciences}

In the area of engineering sciences there are currently very few such models. A prominent example regarding the reduction of duration of studies takes place at the Glyndŵr University Wrexham (Glyndŵr University, 2016). State certified technicians from Germany have the possibility to complete a bachelor's degree in Mechatronics in only three semesters based on recognition of prior learning (Technikakademie der Stadt Braunschweig, 2016). Since not all state certified technicians are able to study and live in Wales for one year, the private professional school of Erfurt came up with the idea to develop such a model at Aalen University.

According to a research report published by Bremen University, state certified technicians can adopt some engineering tasks at companies - so why should these skills need to be taught again at the university? (Tutschner \& Strauß, 2010, p. 29)

In his master's thesis "Development of a recognition model to reduce the duration of studies for state certified technician" (Ihring, 2012), Hannes Ihring developed a model for the recognition of professional skills for state certified technicians with a specialization in mechanical engineering or mechatronics of professional schools located in Bavaria, Baden-Württemberg or Thuringia. This thesis was based on the government founded ANKOM projects. These projects were installed to develop and test methods regarding recognition of prior learning on academic studies. One of these projects was called "bkus-ing", located at the Ilmenau University of Technology (Stamm-Riemer, I. et. al., 2011, p. 100), which tested the recognition of prior learning on engineering sciences. The results of this project formed the basis for the development of the recognition model for certified engineers at Aalen University.

The recognition was verified by both Aalen University and the cooperating professional schools. Additionally, the state certified technicians were included in the consideration in form of self-assessment of their own skills.

With cooperation contracts between Aalen University and the participating professional schools the recognition was fixed. Some schools offer a propaedeutic course in mathematics to prepare their pupils for the upcoming study course.

With this widespread examination, preliminary work and agreement, the new course of study "Mechatronics compact by recognition" (in German "Mechatronik kompakt durch Anerkennung", abbr. MekA) was able to start. All students of this special program receive 53 ECTS by overall recognition. The modules concerned are typically not located in the same semester, so that a complete semester cannot be left out. The recognized items are spread over nearly all seven semesters of the original bachelor course. This would result in a "rag rug" of modules to complete. By thorough reallocation of the remaining modules the gaps have been closed and the duration of studies has been significantly reduced by 2 semesters. With this new sequence of modules, it was very important to verify that the students are able to pass the modules and will not struggle with missing knowledge from a module now placed in parallel to another, which was formerly placed in a higher semester. This was managed by intensive discussions between the staff in charge.

The 53 ECTS are composed of 15 ECTS from the internship which regularly comprises 30 ECTS and 38 ECTS from lectures.

Hannes Ihring compared these study modules with the curriculum for state certified technicians using a moderately structured method (Ihring, 2012, p. 44).

In case of a $75 \%$ match in scope and profoundness a recommendation for recognition was made. Furthermore, all relevant groups were included in discussions, so this recommendation for recognition is broadly validated.

\section{$4 \quad$ Framework}

The resulting consequences for the existing bachelor course in mechatronics are mainly organizational ones: The students of this recognition-study program take part in lectures which are already held for regular students. Hence, no new academic staff is required to teach these students and there is no minimum number of participants.

Consequently, modules are attended by students from different programs of study and semesters. Lecturers are confronted with a new challenge: the students with the technician background already 
have specific knowledge from their professional career, so they go faster and deeper into the topics in the lesson than regular students. During projects, they act like a catalyst: the other students can benefit from the practical and procedural knowledge of this group. These abilities need to be considered and should be encouraged for a better performance in the projects. When scheduling modules this multiusing must be considered, because lectures are used in different semesters and both study courses must run without overlap of lectures. To cover all these specifics, a special examination regulation was created. This adds the ability to rearrange the modules and cut the duration of study to 5 semesters.

To offer this opportunity to as many state certified technicians as possible, the study course is promoted at interested professional schools and at expert conferences. In case of profound interest, a cooperation treaty is signed.

At this point in time Aalen University cooperates with six professional schools located in Bavaria, Baden-Württemberg and Thuringia.

\section{Conclusions}

Recently, eight of eleven students of the first cohort finished their studies successfully after 5 semesters including the bachelor's thesis with grades between 1.0 and 1.3. That is very remarkable, as the majority of students write their thesis in an additional semester. The remaining three MekAs are going to graduate after six semesters. Because it is a new type of study course, we are comparing the grades of these non-traditional students with the grades of traditional students.

Regarding our current group of 20 students, in 57 different exams the group of non-traditional students achieved an overall average grade of 2.17. The comparison group achieved an overall average grade of 2.81. Of course the group of 20 is too small to declare a mainstream trend, but it is at least a very positive signal.

The modules compared here are often the ones with a tendency for lower grades (for example engineering mechanics or mathematics). The grade system of the professional schools is not compatible with the system of the university, so the credited modules are entered with an A (Abbr. for Recognized, in German "Angerechnet"). So these modules do not count for averaging.

The recognition of prior learning for this cohort with their own study program is pretty simple: If the admission requirements are met (state certified technician from a cooperating professional school) a student gets these 53 ECTS recognized via overall recognition. The feedback from company tutors concerning this group of students is consistently positive. Especially the high grade of self-dependence and instantaneous implementation of their ideas and drafts is highly appreciated by the companies.

\section{References}

1. Akkreditierungsrat. (19. Dezember 2014). Rundschreiben Anrechnung. last accessed on 02. february 2016 from http://www.akkreditierungsrat.de/fileadmin/Seiteninhalte/AR/Sonstige/AR_Rundschreiben_Anrechnung.pdf

2. ANKOM, W. B.-I. (Januar 2010). Anrechnungsleitlinie: Leitlinie für die Qualitätssicherung von Verfahren zur Anrechnung beruflicher und außerhochschulisch erworbener Kompetenzen auf Hochschulstudiengänge. Hannover.

3. Bonn, z. (22. Mai 2007). Gesetz zu dem Übereinkommen vom 11. April 1997 über die Anerkennung von Qualifikationen im Hochschulbereich in der europäischen Region. Bundesgesetzblatt Jahrgang 2007 Teil II Nr. 15.

4. DIHK. (2012). Ergebnisse der DIHK-Umfrage bei den Industrie- und Handelskammern Frühsommer 2012. Wirtschaftslage und Erwartungen. Berlin.

5. EFI. (2011). Gutachten zu Forschung, Innovation und technologischer Leistungsfähigkeit Deutschlands. (E. F. Innovation, Hrsg.) Berlin.

6. Freiburg, K. H. (09. Juli 2015). Studien- und Prüfungsordnung Besonderer Teil vom 09. Juli $2015 \S 40$ Bachelorstudiengang Pädagogik. Last accessed on 01. March 2016 from http://www.kh-freiburg.de/fileadmin/ userfiles/2_Studium/5_Studieren/5_Rechtsgrundlagen/StudPOs_Besondere_Teile/StudPO_BA_Paedagogik 09_07_2015.pdf

7. Freitag, W. K., Hartmann, E. A., Loroff, C., Stamm-Riemer, I., \& Völk, D. (2011). Gestaltungsfeld Anrechnung: Hochschulische und berufliche Bildung im Wandel. (R. Buhr, Hrsg.) Waxmann. 
8. Glyndŵr University. (2016). Glyndŵr University - Mechatronics. Last accessed on 08. March 2016 from http://www.glyndwr.ac.uk/en/Europeanstudents/summerschool/Mechatronics/

9. Ihring, H. (2012). Entwicklung eines Anrechnungsmodells zur Verkürzung der Regelstudienzeit für Techniker.

10.KMK. (2002). Anrechnung von außerhalb des Hochschulwesens erworbenen Kenntnissen und Fähigkeiten auf ein Hochschulstudium (I).

11.KMK. (2008). Anrechnung von außerhalb des Hochschulwesens erworbenen Kenntnissen und Fähigkeiten auf ein Hochschulstudium (II). (S. 6). Sekretariat der ständigen Konferenz der Kultusminister der Länder in der Bundesrepublik Deutschland.

12.Kruse, E. (2012). Anrechnung beruflicher Kompetenzen von Erzieherinnen und Erziehern auf ein Hochschulstudium. (D. J. (DJI), Hrsg.) München: Weiterbildungsinitiative Frühpädagogische Fachkräfte (WiFF).

13.Land Baden-Württemberg. (01. Januar 2005). Gesetz über die Hochschulen in Baden-Württemberg. Landeshochschulgesetz - LHG. Baden-Württemberg, Deutschland.

14.Martens, J., Diettrich, A., \& Kati, W. (2014). Anrechnung von außerhalb der Hochschule erworbenen Kompetenzen. Last accessed on 02. February 2016 from http://www.wiwi.uni-rostock.de/fileadmin/Institute/ BWL/WiPaed/2014_Anrechnung_von_au\%C3\%9Ferhalb_der_Hochschule_erworbenen_Kompetenzen.pdf

15.Nickel, S., \& Leusing, B. (2009). Studieren ohne Abitur: Entwicklungspotenziale in Bund und Ländern. Gütersloh: CHE Centrum für Hochschulentwicklung GmbH.

16. Orr, D., Gwosc, C., \& Netz, N. (2011). Social and Economic Conditions of Student Life in Europe. Bielefeld: W. Bertelsmann Verlag GmbH \& Co. KG.

17.Stamm-Riemer, I., Loroff, C., \& Hartmann, E. A. (2011). Anrechnungsmodelle: Generalisierte Ergebnisse der ANKOM-Initiative. HIS:Forum Hochschule.

18. Technikakademie der Stadt Braunschweig. (09. march 2016). FAQs zum Studium an der Glynddwr University in Wrexham/Wales. http://www.technikakademie-bs.de/fileadmin/documents/2015-12-17-FAQs_Wrexham.pdf

19.Tutschner, R., \& Strauß, J. (2010). Techniker/innen und Interessenvertretung: Zur Arbeitssituation und beruflichen Identität von Technikern. Institut Technik und Bildung, Universität Bremen. Bremen: ITB, Universität Bremen. 